\title{
Determination of methylmercury fluxes across the air-water and air-soil interfaces by gas chromatography with electron capture detection
}

Received: 5 October 2004/ Revised: 3 January 2005/ Accepted: 16 January 2005/ Published online: 7 April 2005

(C) Springer-Verlag 2005

\begin{abstract}
A method for the determination of methylmercury $(\mathrm{MeHg})$ fluxes across the air-water and air-soil interfaces was developed using an in situ chamber. The $\mathrm{MeHg}$ in the air coming out of the chamber was captured by a column containing sulfhydryl cotton fiber adsorbent. $\mathrm{MeHg}$ was then desorbed from the column by using $2 \mathrm{~mol} \mathrm{~L}^{-1} \mathrm{HCl}$. The $\mathrm{MeHg}$ in the effluent was extracted with benzene, and determined by gas chromatography with electron capture detection. Finally, the $\mathrm{MeHg}$ flux was calculated using the chamber. The method was applied to simulated experiments, and the results showed that the $\mathrm{MeHg}$ fluxes in the air-water system were higher than those in the air-soil-water system. The method was also successfully applied to the field measurements of an environment polluted by a chemical factory, and the results showed that the $\mathrm{MeHg}$ fluxes across the air-soil and air-water interfaces were $0.21-3.09$ and $0.14-0.79 \mathrm{ng} \mathrm{m}^{-2} \mathrm{~h}^{-1}$, respectively. The method will be a useful tool in the environmental study of $\mathrm{MeHg}$.
\end{abstract}

Keywords Methylmercury $\cdot$ Flux $\cdot$ Gas chromatography $\cdot$ Air $\cdot$ Water $\cdot$ Soil

\section{Introduction}

Human activities, including combustion of fossil fuels, waste incineration, gold mining, and other applications

\footnotetext{
X.-R. Xu (ه) • H.-B. Li · J.-D. Gu

Department of Ecology and Biodiversity, The University of Hong Kong,

Pokfulam Road, Hong Kong

E-mail: xuxr@hkusua.hku.hk

Tel: + 852-22990630

Fax: $+852-25176082$

W.-H. Wang · A. Peng

Research Center for Eco-Environmental Sciences,

Chinese Academy of Sciences,

Beijing 100085, PR China
}

of mercury have significantly increased the release of mercury into the environment. Inorganic mercury can be converted into methylmercury $(\mathrm{MeHg})$ under anaerobic conditions in biological systems, not only through microbial activity but also through chemical methylation in the absence of bacteria. $\mathrm{MeHg}$ is the most toxic among the mercury species because of its volatility and its ability to pass through biological membranes such as the blood/brain barrier and the placenta. It can cause irreversible central nervous system damage and fetal Minamata disease. $\mathrm{MeHg}$ is a global pollutant [1-4].

A number of methods have been proposed for the determination of $\mathrm{MeHg}$, such as, fluorimetry [5], atomic absorption spectrometry [6,7], atomic emission spectrometry [8], atomic fluorescence spectrometry [9], gas chromatography $[10,11]$, high-performance liquid chromatography [12, 13], ion chromatography [14], and capillary electrophoresis $[15,16]$. The different methods have been used for the determination of $\mathrm{MeHg}$ in water [17-19], soil [20-22], and air [23, 24]. Recently, several authors have reviewed methods for the determination of $\mathrm{MeHg}$ in various samples, and their advantages and disadvantages have been pointed out $[2,25,26]$. However, little information is available on the determination of $\mathrm{MeHg}$ flux across the air-water or air-soil interface.

Measurement of $\mathrm{MeHg}$ flux is very important for several reasons. First, we need to know the magnitude and direction of the flux as well as the relative importance of the different source categories. Second, flux measurement or description of the key processes regulating the flux is used to drive atmospheric models. Third, flux measurement is used to validate the output of atmospheric models. The information on fluxes is needed at different spatial scales, and information on fluxes at lower scales is integrated to obtain information at a higher scale level. In this paper, a method for the determination of $\mathrm{MeHg}$ fluxes across the air-water and air-soil interfaces was developed using an in situ chamber by gas chromatography with electron capture detection (GC-ECD). The method was applied to simulated experiments and field measurements. 


\section{Experimental}

\section{Apparatus}

An HP 5890A gas chromatograph (Hewlett-Packard, USA) equipped with an electron capture detector and a HP 3396A integrator was used with a Supelco SPB-1701 fused silica capillary column $(15 \mathrm{~m} \times 0.53-\mathrm{mm}$ i.d., 1.00$\mu \mathrm{m}$ film thickness). An air-sampler (Laoshan Electrical Factory, Shandong, China) was used throughout the experiment. The box-shaped transparent chamber $(80 \times 20 \times 20 \mathrm{~cm})$ was constructed from organic glass, and its bottom-board could be opened.

\section{Reagents}

All reagents were of analytical reagent grade. $\mathrm{MeHg}$ chloride was purchased from Merck (Darmstadt, Germany), and the rest of reagents were obtained from $\mathrm{BDH}$ (Poole, UK). Doubly distilled water was used throughout. The stock solution at a concentration of $1 \times 10^{2} \mathrm{~mol} \mathrm{~L}^{-1}$ of $\mathrm{MeHg}$ chloride was prepared in a water/ethanol mixture $(50: 50, \mathrm{v} / \mathrm{v})$ and stored in the dark at $4^{\circ} \mathrm{C}$. Working standards were freshly prepared daily and handled in brown bottles that were washed before use with nitric acid and doubly distilled water. The sulfhydryl cotton fiber adsorbent was synthesized according to the procedure described in the literature $[27,28]$ and preserved on the brown dryer; $0.1 \mathrm{~g}$ of sulfhydryl cotton fiber adsorbent was placed into a column (sampling-tube), and wetted by diluted hydrochloric acid $(\mathrm{pH}=3)$ prior to use.

\section{Operating procedures}

The bottom-board of the chamber was taken away. The chamber was then gently placed on the surface of soil or water. The air passing through two gas inlet ports entered the chamber. The $\mathrm{MeHg}$ in air coming out of the chamber was captured by two columns containing sulfhydryl cotton fiber adsorbent, which were connected to two gas outlet ports. The flow rate of air through the column was $1.0 \mathrm{~L} \mathrm{~min}^{-1}$.

The $\mathrm{MeHg}$ was desorbed from the column containing sulfhydryl cotton fiber adsorbent by $5 \mathrm{~mL}$ of $2 \mathrm{~mol} \mathrm{~L}^{-1} \mathrm{HCl}$. $\mathrm{MeHg}$ in the effluent was then extracted twice with $0.5 \mathrm{~mL}$ of benzene. The extract was dried with anhydrous $\mathrm{Na}_{2} \mathrm{SO}_{4}$, and analyzed by GCECD. The GC-ECD was carried out under the following conditions: injection port temperature $200^{\circ} \mathrm{C}$, oven temperature $120^{\circ} \mathrm{C}$, detector temperature $300^{\circ} \mathrm{C}$,

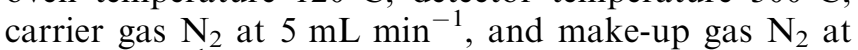
$40 \mathrm{~mL} \mathrm{m^{-1 }}$. Injection volume was $1 \mu \mathrm{L}$, and quantification was based on peak heights using external standard method.

\section{Results and discussion}

Theory for the determination of methylmercury flux

The MeHg fluxes were assessed by using an in situ chamber, which isolated an area of soil (or water) surface and overlaying air (Fig. 1).

The amount of $\mathrm{MeHg}$ collected from the gas outlet of the flux chamber is defined as:

$\mathrm{R}_{1}=\mathrm{R}_{\mathrm{e}}+\mathrm{R}_{\mathrm{c}}+\mathrm{R}_{\mathrm{f}}$

where $R_{\mathrm{e}}$ is the amount of $\mathrm{MeHg}$ entering the flux chamber from the air out of the chamber, $R_{\mathrm{c}}$ is the amount of $\mathrm{MeHg}$ absorbed (or released) by the inner wall of the chamber, and $R_{\mathrm{f}}$ is the amount of $\mathrm{MeHg}$ released (or absorbed) from the soil (or water).

When the same (or another) flux chamber with the bottom-board was used, the amount of $\mathrm{MeHg}$ collected from the gas outlet of the flux chamber is defined as:

$\mathrm{R}_{0}=\mathrm{R}_{\mathrm{e}}+\mathrm{R}_{\mathrm{c}}$

From Eqs. 1 and 2, an equation, $R_{\mathrm{f}}=R_{1}-R_{0}$, was obtained. Thus, $\mathrm{MeHg}$ flux is defined as:

$\mathrm{F}_{\mathrm{mh}}=\mathrm{R}_{\mathrm{f}} / \mathrm{S} / \mathrm{T}$

where $F_{\mathrm{mb}}$ is $\mathrm{MeHg}$ flux, $S$ is the area of soil (or water) covered by the chamber, and $T$ is sampling time. If $F_{\mathrm{mh}}$ is positive, it means that $\mathrm{MeHg}$ is released from the soil (or water) to air; if $F_{\mathrm{mh}}$ is negative, then it means that soil (or water) absorbs the $\mathrm{MeHg}$ from the air.

Determination of methylmercury fluxes in the simulated experiments

In a flux chamber, $2 \mathrm{~L}$ of water and $2 \mathrm{~mL}$ of $1,000 \mu \mathrm{g} \mathrm{L}^{-1} \mathrm{MeHg}$ chloride solution were added. At the same time, $2 \mathrm{~L}$ of water, $250 \mathrm{~g}$ of soil, and $2 \mathrm{~mL}$ of $1,000 \mu \mathrm{g} \mathrm{L}^{-1} \mathrm{MeHg}$ chloride solution were added to another flux chamber. The flux chambers were put on the ground outdoors. Sunlight irradiated the flux chambers directly and the ambient temperature was about $25 \pm 2{ }^{\circ} \mathrm{C}$. The results of the simulated experiments are presented in Tables 1 and 2, respectively.

As can be seen in Tables 1 and 2, the $\mathrm{MeHg}$ fluxes decreased gradually. The reason was that the $\mathrm{MeHg}$ fluxes were correlated to the concentrations of $\mathrm{MeHg}$ in water and this would decrease because $\mathrm{MeHg}$ was emitted into the air from water. In addition, the $\mathrm{MeHg}$ fluxes in the water-air system were greater than those in

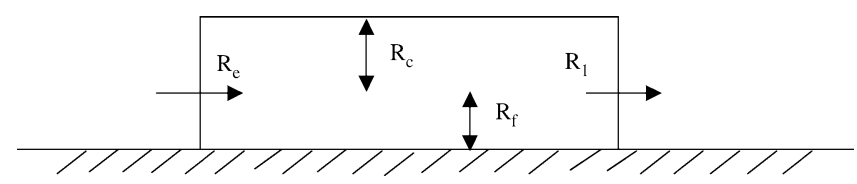

Fig. 1 Mechanism for the calculation of flux 
Table $1 \mathrm{MeHg}$ fluxes across the air-water interface

\begin{tabular}{llll}
\hline Time & $\begin{array}{l}\text { Temperature } \\
\left({ }^{\circ} \mathrm{C}\right)\end{array}$ & $\begin{array}{l}\mathrm{MeHg} \\
\text { in air } \\
\left(\mathrm{ng} \mathrm{m}^{-3}\right)\end{array}$ & $\begin{array}{l}\text { Flux } \\
\text { of MeHg } \\
\left(\mathrm{ng} \mathrm{m}^{-2} \mathrm{~h}^{-1}\right)\end{array}$ \\
\hline 10:30-12:30 & 32 & 411.8 & 154.4 \\
12:30-14:30 & 37 & 177.6 & 66.59 \\
$14: 30-16: 30$ & 37 & 87.75 & 32.91 \\
16:30-18:30 & 36 & 67.42 & 25.28 \\
$18: 30-20: 30$ & 34 & 33.54 & 12.58 \\
20:30-22:30 & 31 & 29.96 & 11.23 \\
\hline
\end{tabular}

Table $2 \mathrm{MeHg}$ fluxes across the air-water-soil interface

\begin{tabular}{llll}
\hline Time & $\begin{array}{l}\text { Temperature } \\
\left({ }^{\circ} \mathrm{C}\right)\end{array}$ & $\begin{array}{l}\mathrm{MeHg} \\
\text { in air } \\
\left(\mathrm{ng} \mathrm{m} \mathrm{m}^{-3}\right)\end{array}$ & $\begin{array}{l}\text { Flux } \\
\text { of } \mathrm{MeHg} \\
\left(\mathrm{ng} \mathrm{m}^{-2} \mathrm{~h}^{-1}\right)\end{array}$ \\
\hline 10:30-12:30 & 32 & 271.2 & 101.7 \\
12:30-14:30 & 37 & 82.21 & 30.83 \\
$14: 30-16: 30$ & 37 & 52.29 & 21.48 \\
16:30-18:30 & 36 & 33.46 & 12.55 \\
$18: 30-20: 30$ & 34 & 30.42 & 11.41 \\
20:30-22:30 & 31 & 28.46 & 10.77 \\
\hline
\end{tabular}

the water-soil-air system (Tables 1 and 2). This was because $\mathrm{MeHg}$ was adsorbed by soil, which would result in lower concentrations of $\mathrm{MeHg}$ in water in the watersoil-air system than in the water-air system.

The limit of detection was $2.5 \mu \mathrm{g} \mathrm{L}^{-1}$, and the relative standard deviations were from 1.7 to $4.5 \%$. The recoveries were in the range of $87-95 \%$. In addition, gas chromatography with electron capture detection for the determination of $\mathrm{MeHg}$ has been validated by fluorimetric and spectrophotometric methods in previous reports $[3,5]$.

Determination of methylmercury fluxes in the field experiments

One sampling site for the air-soil system was near the entrance of a chemical factory, and another was located downwind, about $1 \mathrm{~km}$ away from the factory. The former site was covered with grass, whereas the latter is fertile. The air-water sampling site was located downwind, about $2 \mathrm{~km}$ away from the factory. The results of $\mathrm{MeHg}$ flux measurements are presented in Tables 3, 4, and 5. The $\mathrm{MeHg}$ fluxes across air-soil and air-water

Table $3 \mathrm{MeHg}$ fluxes across the air-soil (covered with grass) interface

\begin{tabular}{llll}
\hline Time & $\begin{array}{l}\text { Temperature } \\
\left({ }^{\circ} \mathrm{C}\right)\end{array}$ & $\begin{array}{l}\mathrm{MeHg} \\
\text { in air } \\
\left(\mathrm{ng} \mathrm{m} \mathrm{m}^{-3}\right)\end{array}$ & $\begin{array}{l}\text { Flux } \\
\text { of } \mathrm{MeHg} \\
\left(\mathrm{ng} \mathrm{m} \mathrm{m}^{-2} \mathrm{~h}^{-1}\right)\end{array}$ \\
\hline $9: 05-10: 35$ & 31 & 36.78 & 0.33 \\
$10: 35-12: 05$ & 37 & 41.50 & 0.21 \\
$12: 05-13: 35$ & 39 & 42.78 & 2.08 \\
\hline
\end{tabular}

Table $4 \mathrm{MeHg}$ fluxes across air-soil interface

\begin{tabular}{llll}
\hline Time & $\begin{array}{l}\text { Temperature } \\
\left({ }^{\circ} \mathrm{C}\right)\end{array}$ & $\begin{array}{l}\mathrm{MeHg} \\
\text { in air } \\
\left(\mathrm{ng} \mathrm{m} \mathrm{m}^{-3}\right)\end{array}$ & $\begin{array}{l}\text { Flux } \\
\text { of } \mathrm{MeHg} \\
\left(\mathrm{ng} \mathrm{m}^{-2} \mathrm{~h}^{-1}\right)\end{array}$ \\
\hline $7: 50-10: 20$ & 29 & 24.67 & 3.09 \\
$10: 20-12: 50$ & 35 & 26.10 & 1.11 \\
$12: 50-15: 20$ & 38 & 25.70 & 0.53 \\
$15: 20-17: 50$ & 37 & 26.23 & 0.43 \\
$17: 50-20: 20$ & 36 & 26.63 & 0.31 \\
$20: 20-22: 50$ & 32 & 25.27 & 1.45 \\
\hline
\end{tabular}

Table $5 \mathrm{MeHg}$ across the air-water interface

\begin{tabular}{llll}
\hline Time & $\begin{array}{l}\text { Temperature } \\
\left({ }^{\circ} \mathrm{C}\right)\end{array}$ & $\begin{array}{l}\mathrm{MeHg} \\
\text { in air } \\
\left(\mathrm{ng} \mathrm{m} \mathrm{m}^{-3}\right)\end{array}$ & $\begin{array}{l}\text { Flux } \\
\text { of } \mathrm{MeHg} \\
\left(\mathrm{ng} \mathrm{m} \mathrm{m}^{-2} \mathrm{~h}^{-1}\right)\end{array}$ \\
\hline $8: 10-12: 10$ & 30 & 15.42 & 0.14 \\
$12: 10-16: 10$ & 38 & 17.96 & 0.41 \\
$16: 10-20: 10$ & 36 & 19.33 & 0.79 \\
\hline
\end{tabular}

interfaces were $0.21-3.09$ and $0.14-0.79 \mathrm{ng} \mathrm{m}^{2} \mathrm{~h}^{-1}$, respectively.

\section{Conclusions}

A method for the determination of $\mathrm{MeHg}$ fluxes across air-water or air-soil interfaces was developed using an in situ chamber with sulfhydryl cotton fiber adsorbent by gas chromatography with electron capture detection. The method was successfully used for the determination of $\mathrm{MeHg}$ fluxes in simulated and real environments. This method will be a useful tool in the environmental study of $\mathrm{MeHg}$.

\section{References}

1. Liu RH, Wang QC, Lu XG, Fang FM, Wang Y (2003) Environ Poll 124:39-46

2. Sanchez Uria JE, Sanz-Medel A (1998) Talanta 47:509-524

3. Li HB, Chen F, Xu XR (2000) J Anal Toxicol 24:704-707

4. Fitzgerald WF, Clarkson TW (1991) Environ Health Persp 96:159-166

5. Li HB, Chen F, Xu XR (2000) Fresenius J Anal Chem 367:499501

6. Burguera JL, Quintana IA, Salager JL, Burguera M, Rondon C, Carrero P, de Salager RA, Petit de Pena Y (1999) Analyst 124:593-599

7. Rio-Segade S, Bendicho C (1999) J Anal At Spectrom 14:263268

8. Menendz Garcia A, Fernandez Sanchez ML, Sanchez Uria T, Sanz Medel A (1996) Mikrochim Acta 122:157-166

9. Jian W, Mena ML, McLeod CW, Rollins J (1994) Int J Environ Anal Chem 57:99-106

10. Liang L, Lazoff S (1999) Talanta 48:231-233

11. Barshick CM, Barshick SA, Walsh EB, Vance MA, Britt PF (1999) Anal Chem 71:483-488

12. Cammann K, Robecke M, Bettmer J (1994) Fresenius J Anal Chem 350:30-33

13. Rio-Segade S, Bendicho C (1999) Talanta 48:477-484 
14. Sarzanini C, Sacchero G, Aceto M, Abollino O, Mentasti E (1994) Anal Chim Acta 284:661-667

15. Medina I, Rubi E, Mejuto MC, Cela R (1993) Talanta 40:16311636

16. Carro-Diaz AM, Lorenzo-Ferreira RA, Cela-Torrijos R (1996) Mikrochim Acta 123:73-86

17. Garcia MF, Garcia RP, Garcia NB, Sanzmedel A (1994) Talanta 41:1833-1839

18. Cai Y, Bayona JM (1995) J Chromatogr A 696:113-122

19. Bowles KC, Apte SC (1998) Anal Chem 70:395-399

20. He B, Jiang GB (1999) Fresenius J Anal Chem 365:615-618
21. Qian J, Skyllberg U, Tu Q, Bleam WF, Frech W (2000) Fresenius J Anal Chem 367:467-473

22. Tu Q, Johnson W, Buckley B (2003) J Anal At Spectrom 18:696-701

23. Larsson T, Frech W (2003) Anal Chem 75:5584-5591

24. Lee YH, Wangberg I, Munthe J (2003) Sci Total Environ 304:107-113

25. Baeyens W (1992) Trends Anal Chem 11:245-254

26. Li HB, Xu XR (1997) Chin J Health Lab Tech 7:243-247

27. Lee YH, Mowrer J (1989) Anal Chim Acta 221:259-268

28. Li HB, Wang WH, Peng A (2000) Chin J Environ Sci 21:81-83 